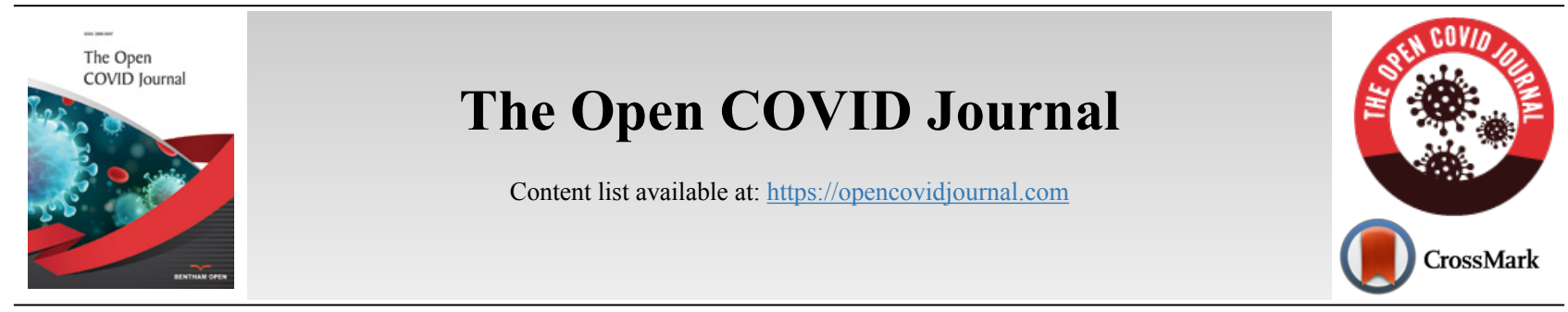

REVIEW ARTICLE

\title{
Challenges and Progress in Vaccine Development for COVID-19 Coronavirus (SARS-CoV-2): A Review
}

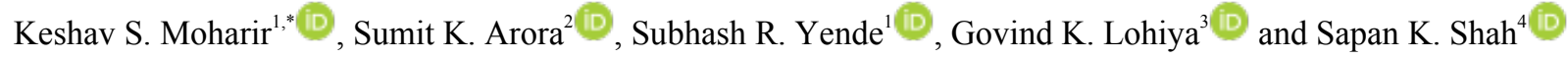 \\ ${ }^{1}$ Department of Pharmaceutics, Gurunanak College of Pharmacy, Nari, Nagpur- 440 026, Maharashtra, India \\ ${ }^{2}$ Department of Pharmacognosy and Phytochemistry, Gurunanak College of Pharmacy, Nari, Nagpur- 440 026, Maharashtra, India \\ ${ }^{3}$ Department of Pharmacology, Gurunanak College of Pharmacy, Nari, Nagpur- 440 026, Maharashtra, India \\ ${ }^{4}$ Department of Pharmaceutical Chemistry, Priyadarshini J. L. College of Pharmacy, Nagpur-440016, Maharashtra, India
}

\begin{abstract}
:
Coronavirus Infectious Disease (COVID-19) has taken heavy toll on human lives and world economy across the globe. Till date, there is no specific treatment and pathological effects in COVID-19 are continuously evolving. The governments and authorities have announced various measures for personal care with use of face masks, physical distancing and prohibition of mass gatherings. These measures have certainly helped to contain the disease but with substantial economic slowdown. Thus mass immunization by vaccination is the top priority. With knowledge of MERS-SARS (Middle East Respiratory Syndrome and Severe Acute Respiratory Syndrome) in hand, researchers are rushing to vaccine development against SARS-CoV-2 (Severe Acute Respiratory Syndrome Coronavirus 2) with newer technological platforms. However, the challenge lies in proving safety, quality and efficacy of vaccine with its resilience to manufacture it in large scales within stipulated time frame. The time consuming nature of classical phased clinical trials are substituted by human volunteer challenge with vaccination of humans engaging undertrial vaccine. This review discusses about various technology platforms being used and tried, their types and challenges in development of vaccine for SARS-CoV-2. Briefly, Indian perspective is also discussed in the race of vaccine development.
\end{abstract}

Keywords: SARS-CoV-2, COVID-19, Vaccine technology, Advances, Challenges, Infectious disease.

\begin{tabular}{|l|l|l|l|}
\hline Article History & Received: January 09, 2021 & Revised: March 30, 2021 & Accepted: April 19, 2021
\end{tabular}

\section{INTRODUCTION}

Until December 2019, Human Coronaviruses (HCoVs) were treated as trivial pathogens, leading to simple "common cold or seasonal flu, mild and self-limiting" in healthy people. However, the 21 st century witnessed 2 pathogenic $\mathrm{HCoVs}$ - Severe Acute Respiratory Syndrome Coronavirus (SARS-CoV) and the Middle East Respiratory Syndrome Coronavirus (MERS-CoV). These viruses are initially transmitted from animals as carriers resulting in epidemics with high morbidity and mortality. The month of December in 2019 broke the news of one more pathogenic virus christened as SARS-CoV-2 and resulting infection as Coronavirus Disease 19 (COVID-19). The first location of this outbreak was reported in Wuhan city in the Hubei province of China [1, 2]. The initial stages involved clusters of pneumonia cases in January 2020. This was followed by the spread of the virus across the globe, eventually WHO declaring it as pandemic on $11^{\text {th }}$ March 2020 [3].

\footnotetext{
* Address correspondence to this author at the Department of Pharmaceutics, Gurunanak College of Pharmacy, Nari, Nagpur, Maharashtra-440026, India; >Tel: +919970854870; Email: keshavmoharir@gmail.com
}

While the pathological changes, co-existence of other diseases, and line of treatment in COVID-19 patients are still under investigation and evolving as the disease progresses, experts are banking heavily on the rapid development of the safe and efficacious vaccine. The only way right now to prevent the spread of infection is by physical distancing, avoiding large gatherings, use of face masks, and Personal Protective Equipment (PPE) kits. The long-term solution for COVID-19 will be a global vaccination program for socioeconomic and therapeutic benefits. As of today, the total number of confirmed COVID-19 cases is 33.2 millions, with 999,239 deaths [4]. Since the treatment of COVID-19 is symptomatic without a fixed line of treatment, there is an urgency to develop the vaccine against SARS-CoV-2. This article covers possible avenues in vaccine development for SARS-CoV-2 and is based on current research projects being carried out all over the world. It also aims to explore challenges and approaches in the development of an effective vaccine against SARS-CoV-2.

\section{STRUCTURE OF SARS-CoV-2}

SARS-CoV-2 belongs to Coronaviridae family, order 
Nidovirales. It is either spherical in shape or pleomorphic with a diameter of $125 \mathrm{~nm}$ featured by club-shaped spike projections on its surface, commonly called 'Corona' due to its peculiar shape [5]. The virus has 14 days incubation period with common symptoms of common cold, dry cough, fatigue, fever, nasal congestion, labored breathing progressing to respiratory and cardiac failure, eventually leading to death [1]. SARS$\mathrm{CoV}-2$ is the enveloped virus that contains segmented, positive sense, single stranded-RNA genome of around $30 \mathrm{~kb}$, largest among all the RNA viruses [6]. In consonance with other Coronaviruses, SARS-CoV-2 has four structural proteins.

(1) Glycosylated Spike (S) protein which forms a trimer on virus surface to take the shape of the crown. Its structure shows the presence of two domains S1 and S2, representing to carry out the major function as Receptor Binding Domain (RBD) for attachment to the surface of host receptor cell and fusion with host cells respectively [7].

(2) Nucleoside $(\mathrm{N})$ protein helps to replicate the viral genome inside the host cell.

(3) Membrane (M) transmembrane glycoprotein, which maintains viral structure and assembly, and

(4) Envelope (E) protein plays a role in the virulence, pathogenesis, and release of virus $[8,9]$. SARS-CoV-2 gains entry into the host cell after binding of RBD and then attachment with Angiotensin-Converting Enzyme 2 (ACE 2) receptors prevalent on human cells with higher affinity than other receptors [10].

Fig. (1) gives an idea about the structure of Coronavirus with the location of structural proteins and respective functions [11]

\section{NEED FOR VACCINE AGAINST COVID-19}

There have been several studies and ongoing clinical trials to find a precision medicine for COVID-19 treatment and prophylaxis. Among all these studies, remdesivir has proven to be effective in reducing median time for recovery from 15 days to 11 days and diminished the mortality rate from $11.9 \%$ to
$7.1 \%$ [12]. However, the effectiveness of remdesivir in the patients with severe COVID-19 infection was not significant statistically as well as clinically [13]. In yet another randomized, open-labeled phase 2 study, combination therapy of oral ribavirin (a nucleoside analog) and oral lopinavir+ritonavir (protease inhibitors) indicated alleviation of symptoms if given within 7 days, nonetheless failed to impress in patients with severe COVID-19 infection and chronic comorbidity [14]. Although there are several undergoing clinical trials targeted towards COVID-19 since its outbreak, none of the new or repurposed drugs are found clinically suitable as an antiviral specifically towards SARS-CoV-2. For this reason, the development of safe and effective vaccines followed by mass-scale vaccination across the globe is vital to reduce mortality rate and the number of cases globally. Accordingly, consolidated efforts have led to the development of several vaccines and being supplied to the world through coordinated and planned execution. Further, another possibility is that COVID-19 may sometime later become, a seasonal or recurrent disease requiring an accurate and precise treatment for all. Additionally, convalescent plasma from recovered COVID-19 patients that include monoclonal antibodies (H2, $\mathrm{H} 4, \mathrm{~B} 5$, and B38) have exhibited positive outcomes with respect to high neutralization of viral antigens. However, isolation of such plasma from aged patients with co-morbidity, allergic reactions in plasma recipients and antibodies formed against SARS-CoV-2 waning off from blood of donors are deterring factors for convalescent plasma therapy $[15,16]$. Most recently, the appearance of SARS-CoV-2 variant strains with spike protein mutations reported in the United Kingdom (strain B.1.1.7) and Republic of South Africa (strain B.1.351) have raised concerns about re-emergence of COVID-19, although Moderna mRNA-1273 vaccine has confirmed about 94\% efficacy in a Phase 3 study against new variants [17]. Among the worst affected countries, Brazil has faced more than 60,000 deaths due to COVID-19 in the month of March, pushing health services to the tipping point where the only hope is vaccination [18]. Thus, all these important discussions reconfirm the need for vaccination on a large scale to protect people against SARS-CoV-2 infection.
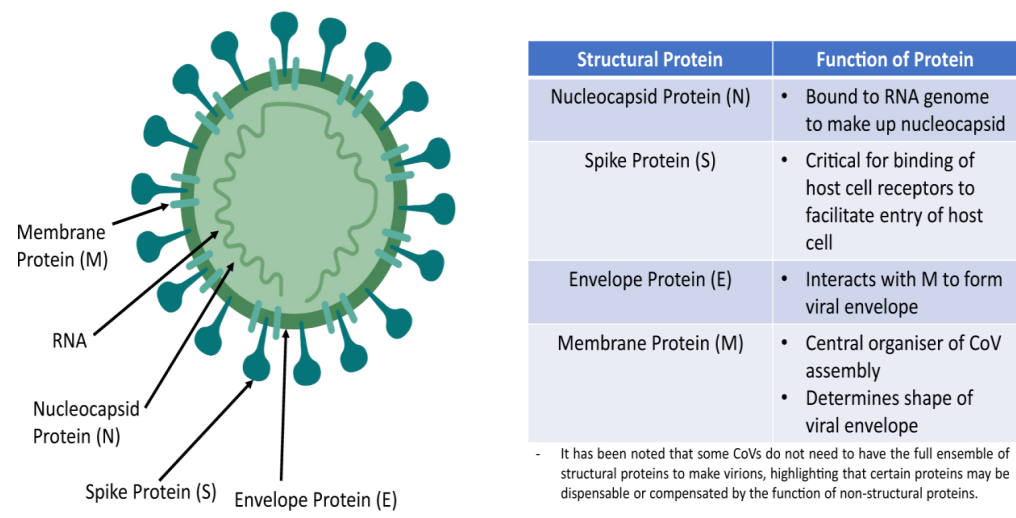

Fig. (1). Structure of Coronavirus with main proteins and their functions. Adapted from [11]. 


\section{CHALLENGES IN SARS-CoV-2 VACCINE DEVELOPMENT}

SARS-CoV-2 is a baffling type of RNA virus. Many patients show clinical symptoms while many are asymptomatic. The main challenge in vaccine development is a high rate of mutation and RNA recombination in RNA viruses, which are highly adapted to changing environments [19 - 21]. This is also accompanied by zoonotic virus transmission to humans. The rate of replication of this virus is extremely high having noteworthy genetic diversity [22]. The S-protein is a glycoprotein envelope on SARS-CoV-2, which primarily determines protective immunity. This is further divided as S1 and S2 subunit playing the role of viral receptor binding and membrane fusion, respectively. The difficulty of targeting these proteins lies in the fact that both the protein subunits undergo pre-fusion and post-fusion conformational changes representing altogether different antigenic epitopes [23]. The previous knowledge of MERS-CoV cannot be applied fully for COVID-19 vaccine development as a similarity between the Sprotein of SARS-CoV-2 and MERS-CoV is only $44 \%$ [24].

Another aspect during vaccine development is its clinical trials. The clinical trials on human volunteers are preceded by pre-clinical trials employing suitable animal models. Preliminary animal studies have shown the development of neutralizing antibodies against S1 subunit of S-protein [25]. However, the preliminary studies have shown inflammatory response and altered pathological conditions like pulmonary eosinophilic infiltration in alveolar regions of animals (nonhuman primates) on exposure to the viral challenge tests [26 28]. This was one of the reasons for one school of thought that questioned hastily and rushed human trials without assessing efficacy, safety and toxicology studies. This specifically has been said about Moderna and the National Institute of Allergic and Infectious Diseases (NIAID) in the US, which conducted clinical trials for mRNA-based vaccine candidates against SARS-CoV-2 [29]. Formulation of vaccine is an altogether additional challenge as new techniques of vaccine formulation are scantily tested for compatibility of antigenic substance with adjuvants and vaccine vehicle. Scale up to produce millions of doses is also a mammoth task. From a regulatory point of view, there is disparity among standards set by different regulatory agencies. Greater harmonization is to be sought when the question of emergency use authorization arises. Even though there is successfully shortened vaccine development time almost from a decade to fewer than twelve months, a clear and transparent development process, as well as clinical outcome, needs to be made available with understandable evidence that this has not jeopardized patient safety.

Developed and approved vaccines further require to be made available to the susceptible population of the society at the right time and at affordable price. There have been reports of more than 10,000 COVID-19 related deaths per day worldwide, compelling grueling and ambitious plans to ramp up the vaccination. However, large-scale production and mass scale distribution of vaccines with cold chain storage seem challenging in the low-income countries. Keeping logistics, supply chain management and vaccine scheduling apart, a more challenging task to be dealt with is improving public awareness for vaccination and hesitancy as well as spread of misinformation and rumors among the target population. Alleviating concerns of vaccine side effects and effectiveness have to be prioritized by governments for quicker vaccination scheduling [30]. A recent survey based study from several countries tells that maximum $77.6 \%$ of people (of mixed age, gender, ethnicity, religion, professionals, personal beliefs, education and income) are ready to accept COVID-19 vaccine, figures indicating a worrisome trend while achieving maximum vaccination in susceptible population [31]. On the clinical front, the duration for which immunity conferred by the vaccine lasts and the time gap between two successive doses of vaccines is established clearly but with some varying data, although vaccination has been started aggressively in many countries.

Bao et al. have reported that commonly used animals in pre-clinical studies are not suitable for developing the COVID-19 vaccine as they are not prone to SARS-CoV-2 virus infection. Thus, a major challenge is availability of incomplete or insufficient data owing to lack of well established animal disease model. This has posed a problem in the initial stages for selection of candidate vaccine as well as immunogenicity triggered by the vaccine [32].

\section{STRATEGIES OF VACCINE DEVELOPMENT AGAINST SARS-CoV-2}

Vaccines for active immunization involve antigenic material and work by triggering the immune system of the host to produce antibodies specific to that antigen, while passive immunization involves readymade antibodies specific for the disease causative agents, such as bacteria or viruses. In the conventional or classical type of vaccine, an epitope from the causative micro-organism is identified, isolated, purified, tested at the preclinical stage followed by clinical trials and then used for mass-scale immunization after approval. These may be in the form of live attenuated (weakened pathogenicity), inactivated (killed), subunit or conjugate vaccine and in the form of toxoids [33]. Thus the vaccine triggers up host immunity to produce antibodies against the pathogen. On subsequent exposure to the pathogen, the host immunity responds in a better manner due to existing antibodies in circulation. This type of vaccine takes approximately 12 to 15 years to development, precluding early release of vaccine for mass population [34]. One more issue of consideration is the selection of proper adjuvants the therapeutically inactive components of vaccine formulations. If the adjuvants are not correctly selected, the immunological response is suboptimal, particularly more affirming with modern types of vaccines as they are under continuous evolution $[35,36]$.

The ongoing discussion makes it clear that classical means of vaccine development for SARS-CoV-2 will consume a lot of time till it is in final use. This allows the scope for vaccine development by advanced and evolving newer strategies [37]. The vaccines for COVID-19 development is fast tracked but with a lack of detailed preclinical studies on nonhuman primates (NHPs) [38, 39]. For the sake of understanding, Fig. (2) explains the classical $V s$ COVID-19 vaccine development in sequential stages [40]. 
In the process of vaccine approval, comprehensive data of pre-clinical trials and Phase 1,2 and 3 of human clinical trials is submitted to regulatory bodies. Phase 1 trials on 20 to 100 healthy volunteers focus on safety establishment, Phase 2 trials on few hundred to few thousands of volunteers set goal on evaluating protective, safe and efficacious dose followed by Phase 3 trials on several thousand volunteers for getting clinical, quantifiable end point concerned with the disease in the question. Apparently, The current strategy of testing the safety and efficacy of the SARS-CoV-2 vaccine may jeopardize Phase III studies replacing it by controlled human challenge studies. The pool of human volunteers involves those who are uninfected with the virus, and another group includes volunteers having the highest risk of getting infected from SARS-CoV-2 naturally (those who are not infected but living in containment zone). Both groups are stated to be comprised of volunteers in the age group of 18 to 60 years selected carefully, which are otherwise at low risk of mortality and less

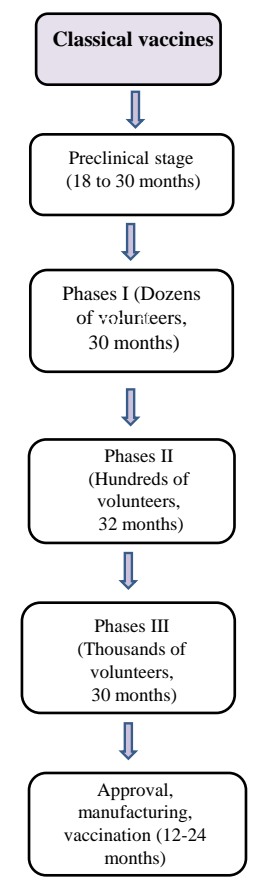

likely to harbor infection after dosing [41 - 43]. Currently, the National Institute of Allergic and Infectious Disease (NIAID) sponsored and collaborated by Moderna studies are being conducted across the US. The vaccine candidate being tested is mRNA-1273, a novel lipid nanoparticle (LNP)-encapsulated mRNA-based vaccine for SARS-CoV-2 that encodes for a fulllength, stabilized surface spike (S) protein [44].

The manufacturing facilities are provided by the Coalition for Epidemic Preparedness Innovations (CEPI) [45]. As of today's date, 13 candidate vaccines are under clinical evaluation as mentioned in Table 1 [46]. Apart from this, 128 candidate vaccines are under the preclinical evaluation stage for COVID-19, out of which 11 are DNA vaccines, 5 inactivated, 3 live attenuated, 17 non replicating viral vector, 49 protein subunit, 15 replicating viral vector, 15 RNA (liposome, lipid nanoparticle and lipid encapsulated mRNA), 10 VLP (virus like particles) and 3 of unknown/ undisclosed platform [46].

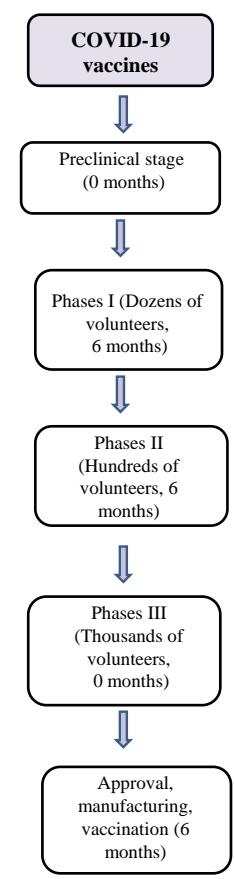

Fig. (2). Comparison between developmental stages of conventional/classical vaccine against SARS-CoV-2 Vaccine. Adapted from [40].

Table 1. Draft landscape of COVID-19 candidate vaccines under clinical investigation. This table shows vaccines that are successful in clearing the preclinical stage, as updated on $18^{\text {th }}$ June 2020 [46].

\begin{tabular}{|c|c|c|c|c|c|}
\hline Platform & $\begin{array}{c}\text { Type of Candidate } \\
\text { Vaccine }\end{array}$ & Developer & $\begin{array}{c}\text { Coronavirus } \\
\text { Target }\end{array}$ & $\begin{array}{c}\text { The Current Stage of Clinical } \\
\text { Evaluation/Regulatory Status- } \\
\text { Coronavirus Candidate }\end{array}$ & $\begin{array}{c}\text { Same Platform for } \\
\text { Non-Coronavirus } \\
\text { Candidates }\end{array}$ \\
\hline $\begin{array}{c}\text { Non- } \\
\text { Replicating } \\
\text { Viral Vector }\end{array}$ & ChAdOx1-S & $\begin{array}{c}\text { University of } \\
\text { Oxford/AstraZeneca }\end{array}$ & SARS-CoV2 & $\begin{array}{c}\text { Phase2b/3 } \\
2020-001228-32 \\
\text { Phase } 1 / 2\end{array}$ & $\begin{array}{c}\text { MERS, influenza, TB, } \\
\text { Chikungunya, Zika, } \\
\text { MenB, plague }\end{array}$ \\
\hline $\begin{array}{c}\text { Non- } \\
\text { Replicating } \\
\text { Viral Vector }\end{array}$ & $\begin{array}{c}\text { Adenovirus Type 5 } \\
\text { Vector }\end{array}$ & $\begin{array}{c}\text { CanSino Biological } \\
\text { Inc/Beijing Institute of } \\
\text { Biotechnology }\end{array}$ & SARS-CoV2 & Phase 2 ChiCTR2000031781 & Phase 1 \\
ChiCTR2000030906 & \\
\hline
\end{tabular}




\begin{tabular}{|c|c|c|c|c|c|}
\hline Platform & $\begin{array}{c}\text { Type of Candidate } \\
\text { Vaccine }\end{array}$ & Developer & $\begin{array}{c}\text { Coronavirus } \\
\text { Target }\end{array}$ & $\begin{array}{c}\text { The Current Stage of Clinical } \\
\text { Evaluation/Regulatory Status- } \\
\text { Coronavirus Candidate }\end{array}$ & $\begin{array}{l}\text { Same Platform for } \\
\text { Non-Coronavirus } \\
\text { Candidates }\end{array}$ \\
\hline RNA & $\begin{array}{c}\text { LNP- } \\
\text { encapsulated mRNA }\end{array}$ & Moderna/NIAID & SARS-CoV2 & $\begin{array}{l}\text { Phase } 2 \text { NCT04405076 } \\
\text { Phase } 1 \text { NCT04283461 }\end{array}$ & multiple candidates \\
\hline Inactivated & Inactivated & $\begin{array}{c}\text { Wuhan Institute of Biological } \\
\text { Products/Sinopharm }\end{array}$ & SARS-CoV2 & Phase 1/2 ChiCTR2000031809 & - \\
\hline Inactivated & Inactivated & $\begin{array}{l}\text { Beijing Institute of } \\
\text { Biological } \\
\text { Products/Sinopharm }\end{array}$ & SARS-CoV2 & Phase 1/2 ChiCTR2000032459 & - \\
\hline Inactivated & Inactivated + alum & Sinovac & SARS-CoV2 & $\begin{array}{c}\text { Phase } 1 / 2 \text { NCT04383574 } \\
\text { NCT04352608 }\end{array}$ & SARS \\
\hline Protein Subunit & \begin{tabular}{|c|} 
Full length \\
recombinant SARS \\
CoV-2 \\
glycoprotein \\
nanoparticle vaccine \\
adjuvanted \\
withMatrix M
\end{tabular} & Novavax & SARS-CoV2 & Phase $1 / 2$ NCT04368988 & $\begin{array}{l}\text { RSV; CCHF, HPV, } \\
\text { VZV, EBOV }\end{array}$ \\
\hline RNA & 3 LNP-mRNAs & $\begin{array}{l}\text { BioNTech/Fosun } \\
\text { Pharma/Pfizer }\end{array}$ & SARS-CoV2 & $\begin{array}{c}\text { Phase } 1 / 2 \\
2020-001038-36 \\
\text { NCT04368728 }\end{array}$ & - \\
\hline Inactivated & Inactivated & $\begin{array}{c}\text { Institute of Medical Biology } \\
\text {, Chinese Academy of } \\
\text { Medical Sciences }\end{array}$ & SARS-CoV2 & Phase 1 NCT04412538 & - \\
\hline DNA & $\begin{array}{l}\text { DNA plasmid vaccine } \\
\text { with electroporation }\end{array}$ & Inovio Pharmaceuticals & SARS-CoV2 & Phase 1 NCT04336410 & multiple candidates \\
\hline $\begin{array}{l}\text { Non- } \\
\text { Replicating } \\
\text { Viral Vector }\end{array}$ & Adeno-based & Gamaleya Research Institute & SARS-CoV2 & Phase 1 & - \\
\hline RNA & saRNA & Imperial College London & SARS-CoV2 & Phase 1 & $\begin{array}{c}\text { EBOV; LASV, MARV, } \\
\text { Inf (H7N9), RABV }\end{array}$ \\
\hline RNA & mRNA & Curevac & SARS-CoV2 & Phase 1 & $\begin{array}{l}\text { RABV, LASV, YFV; } \\
\text { MERS, InfA, ZIKV, } \\
\text { DENV, NIPV }\end{array}$ \\
\hline
\end{tabular}

\subsection{Vaccine Targets}

SARS-CoV-2 shows four main structural proteins; the three are expressed on the surface of the viral particles - the spike (S), the membrane (M), and the envelope (E), while the fourth structural protein, nucleocapsid $(\mathrm{N})$ is associated with the viral RNA within the virus. It also shows 15 nonstructural proteins and 12 accessory structural proteins. Of these, spike proteins, envelope (E) and membrane (M) proteins, open reading frames (ORF) and nucleocapsid proteins are potentially significant targets for various vaccines. Surface glycoproteins (S) have two subunits S1 and S2. Subunit S1 helps the virus bind with host receptor angiotensin-converting enzyme 2 (ACE2) via Receptor Binding Domains (RBD) and the S2 subunit mediates fusion of viral and host membrane by viral fusion peptide. These bring about conformational changes leading to the entry of the viral genome, making it the main target for vaccines. Membrane (M) and envelope (E) proteins form the bulk of the structural proteins forming the shell of the virus. E protein is assumed to support ion channels in replication, while $\mathrm{M}$ protein promotes viral assembly and budding. Nucleocapsid (N) protein is closely involved in viral translation and transcription, a potential target for vaccines that trigger CD4+ and CD8+ T cells formation against $\mathrm{N}$ protein. The open reading frame (ORF), mainly ORF3a and ORF7a, are part of transmembrane accessory proteins; although their roles are not exactly established, they can be targeted by vaccines to initiate antibody response [47 - 49].

\subsection{Formulation of Vaccines}

Many parameters are involved in selecting the formulation method and manufacturing process of vaccines. Ingredients in the vaccine can be divided into two parts - antigenic material and non antigenic substance, commonly called adjuvants. The excipients to be selected depend on the route of administration, technology platform to be used, dose, physical nature (solution/emulsion/suspension), as well as handling and storage temperature. Table 2 throws light on non-antigenic excipients used in SARS-CoV-2 vaccine formulation.

Inactivated types of vaccines are the most commonly used form of vaccines, with established formulation strategies. Alum is the usual adjuvant that adsorbs the main contents which help to slowly release components and gradual development of immunity. Apart from Sinovac, inactivated SARS-CoV-2 virus is being used and under Phase 3 trials in Brazil (NCT04456595), Turkey (NCT045823440), and Indonesia (INA-WXFM0YX) [50]. Subunit vaccines use one or more parts of the pathogen in vaccine formulation. Clover Biopharmaceuticals Australia (NCT04405908) and Medigen Vaccine Biologics Corporation, the National Institute of Allergy and Infectious Disease (NIAID) are employing stabilized spike proteins of SARS-CoV-2 with alum and $\mathrm{CpG}$ 1018 (unmethylated oligodeoxynucleotide - ODN), giving booster effect and significant virus neutralizing titers [51]. A vaccine in the form of protein nanoparticles is being developed by Novavax, wherein soluble protein aggregates are 
transformed into nano size by using non-ionic surfactant polysorbate 80 in phosphate buffer [52]. Similarly, Medicago is in the process of entering into Phase 1 Clinical Trials for a COVID-19 vaccine (NCT04450004) that employs Virus-Like Particles (VLP) form of components adsorbed on alum.

\section{TYPES OF VACCINES AND PLATFORMS USED AGAINST SARS-CoV-2}

Progress in vaccine development is evident in last two decades since the outbreak of Ebola, SARS, MERS, H1N1, Zika viruses and a few more to count. The issues and concerns associated with vaccine development cover not only safety, efficacy, quality, and toxicology but also scale-up technology, versatility, stability and proper supply chain management to cater to the world population. An account of approaches for the vaccine types is mentioned in Fig. (3) [40]. Here, we now discuss new technological advances and platforms in development of vaccines against SARS-CoV-2.

Table 2. Overview of components used in SARS-CoV-2 vaccine formulation [48, 49].

\begin{tabular}{|c|c|c|c|c|}
\hline $\begin{array}{c}\text { Component/ } \\
\text { Adjuvant }\end{array}$ & Vaccine candidate (type of antigen) & Description & Mechanism & $\begin{array}{c}\text { Storage } \\
\text { conditions }\end{array}$ \\
\hline RNA & $\begin{array}{l}\text { Moderna (mRNA), Pfizer (mRNA \& } \\
\text { replicon mRNA) }\end{array}$ & $\begin{array}{l}\text { Stimulates immune response by } \\
\text { encoding antigenic constructs }\end{array}$ & $\begin{array}{l}\text { TLR (Toll like receptors) } \\
\text { stimulation }\end{array}$ & $-20^{\circ} \mathrm{C}$ \\
\hline $\begin{array}{l}\text { Polysorbate } \\
80 / \text { Tween } 80\end{array}$ & Novavax (Recombinant protein) & A non ionic surfactant & $\begin{array}{c}\text { Inhibits protein adsorption } \\
\text { to potentially denaturing } \\
\text { interfaces, stabilizes } \\
\text { emulsion }\end{array}$ & $2-8^{\circ} \mathrm{C}$ \\
\hline Advax-SM & Vaxine Pty/Medytox (Recombinant Protein) & Inulin microparticles & $\begin{array}{c}\text { Antigen presenting cell } \\
\text { dependant }\end{array}$ & \\
\hline Alum & $\begin{array}{c}\text { Bharat Biotech(Inactivated Virus), } \\
\text { Sinovac (Inactivated Virus), } \\
\text { Clover (With CpG 1018,Recombinant } \\
\text { Protein) }\end{array}$ & $\begin{array}{l}\text { Salt forms -aluminum hydroxide or } \\
\text { aluminum phosphate }\end{array}$ & Multiple effects & $2-8^{\circ} \mathrm{C}$ \\
\hline CpG 1018 & $\begin{array}{c}\text { Medicago (VLP), } \\
\text { Clover (With Alum, Recombinant Protein), } \\
\text { Medigen/NIAID/Dynavax } \\
\text { (RecombinantProtein) }\end{array}$ & $\begin{array}{c}\text { Non-methylated } \\
\text { oligodeoxynucleotide (ODN) }\end{array}$ & $\begin{array}{l}\text { TLR } 9 \text { triggering } \\
\text { mechanism }\end{array}$ & $2-8^{\circ} \mathrm{C}$ \\
\hline Ionizing lipids & $\begin{array}{c}\text { Pfizer (mRNA and } \\
\text { replicon RNA), } \\
\text { Pfizer (mRNA and replicon RNA), } \\
\text { Arcturus (replicon RNA }\end{array}$ & $\begin{array}{l}\text { Lipids containing amino groups which } \\
\text { become cationic at acidic } \mathrm{pH} \text {. }\end{array}$ & $\begin{array}{l}\text { potentially stimulate } \\
\text { TLR2/TLR4 }\end{array}$ & $-20^{\circ} \mathrm{C}$ \\
\hline
\end{tabular}

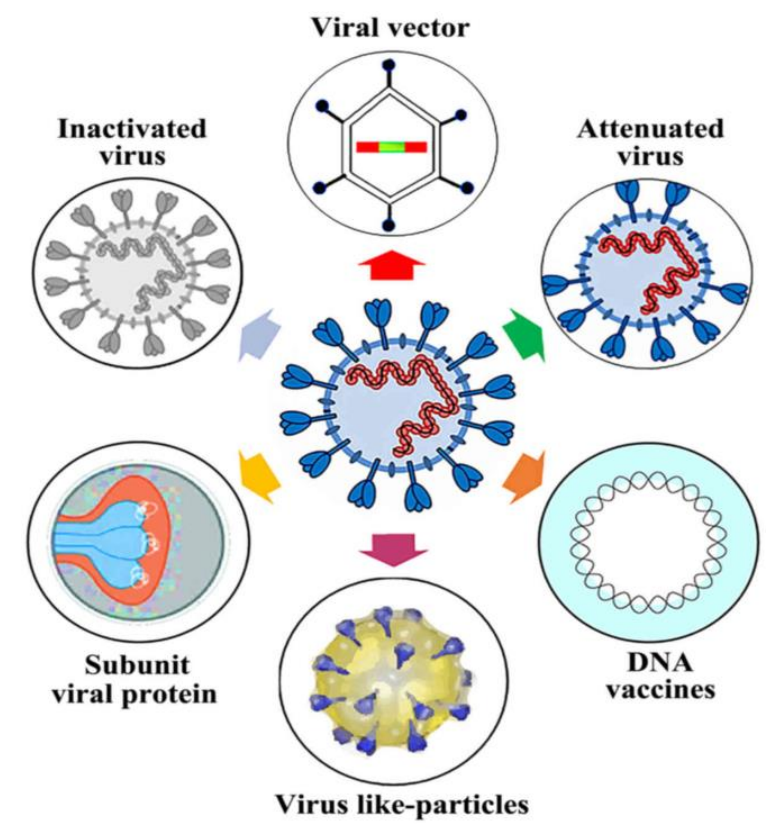

Fig. (3). Approaches for development of SARS-CoV-2 Vaccine. Adapted from [40]. 


\subsection{Nucleic Acid Type Vaccines}

This comprises RNA and DNA vaccines. Protein $\mathrm{S}$ is the main surface protein of Coronavirus, which helps to gain entry into the host cell through which the viral genome enters the host cells, replicates and initiates infection. Moderna company has developed an mRNA vaccine with viral proteins, which, when injected, produces new coronavirus proteins so that the host immune system can recognize them [53, 54]. DNA vaccines are recombinant DNA technology-based vaccines involving genetic manipulations. A suitable viral vector or plasmid is used to deliver the required DNA. The plasmid is accompanied by a promoter motif that initiates immune triggering protein synthesis [55]. DNA vaccine stimulates both cellular and humoral immunity, is stable and provides longterm immunity [56]. This DNA vaccine is referred as ChAdOx1 nCoV-19, mainly developed to prevent MERS. The principle of this vaccine is based on an adenovirus vaccine vector producing highly antigenic SARS-C OV-2 spike protein, resulting in the formation of antibodies. The Moderna mRNA-1273 vaccine in pre-clinical trials in mouse and rhesus macaques showed total protection from viral replication in lungs at $10 \mu \mathrm{g}$ dose level even after 13 weeks of vaccination [57]. Phase 1 clinical trial at $100 \mu \mathrm{g}$ dose reported the reduction of SARS-CoV-2 infection by at least $80 \%$ while placebo-controlled phase 3 trial (ClinicalTrials.gov NCT04470427) confirmed efficacy and safety criteria with $94 \%$ estimated efficacy.

\subsection{Viral Vector Vaccines}

These are the vaccines wherein the genome of one virus carries an antigenic genome of another virus. Both the viruses are weakened so that antigenicity of one is retained while virulence and pathogenicity is drastically reduced. These can be developed as either replicating (like attenuated measles) or non-replicating viral vectors (adenovirus vector). They can induce both $\mathrm{B}$ cell as well as $\mathrm{T}$ cell responses [58]. Enteric adenovirus and human adenovirus 5 have been used in the past to deliver MERS-CoV surface (S) protein. Johnson and Johnson company is working on this approach [59].

Viral vectors like Adeno-Associated Virus (AAV) have been approved by FDA previously. In recent days, Nonreplicating and replicating adenoviruses have been developed for SARS-CoV-2 vaccines. CanSino is manufacturing a vaccine against SARS-CoV-2 using an adenovirus type 5 (Ad5) vector. Phase 2 Clinical trials indicated the development of SARS-CoV-2 specific antibodies in 28 days in $100 \%$ patients without significant side effects [60]. Furthermore, Oxford - AstraZeneca have collaboratively developed COVID-19 vaccine with an adenoviral vector originating from a chimpanzee adenovirus and that encodes $\mathrm{S}$ protein (ChAdOx1 nCoV-19). Two doses, a prime dose on day 0 and a booster dose on day 28 given in Phase 2 trials, reported 100\% neutralizing antibody titer (ClinicalTrials.gov, NCT04324606). At the end of the Phase 3 trial, this vaccine reported $70 \%$ efficacy [61].

\subsection{Protein Subunit Vaccines}

Protein subunit vaccines are developed with a specific part of the pathogen responsible for the production of antibodies. This means an antigenic determinant like surface protein fragments, protein $\mathrm{S}$ in the case of SARS-CoV-2 is used. Since a very small quantity of antigen is used, they are often weak and added with other carrier protein molecules. They may also contain aluminum salt as an adjuvant [62]. The SARS-CoV-2 vaccine being investigated mainly focuses on the Receptor Binding Domain (RBD) of spike protein on the virus surface. Preclinical studies have shown protection from SARS-CoV infection in mice when used with Freund's adjuvant. The outcome of immune response to large extent depends upon the selection of adjuvants and combination of adjuvants as they show synergistic response [63]. The COVID-19 vaccine being tested by Novavax is a protein subunit vaccine that incorporates transmembrane spike protein S. This NVXCoV2373 vaccine uses Matrix-M adjuvant that results in higher IgG titers against $\mathrm{S}$ protein, as reported in the preclinical studies [64]. Placebo controlled Phase 2a studies have shown that two doses- prime dose and booster dose on $21^{\text {st }}$-day yield improved CD4+ T-cell responses (ClinicalTrials.gov NCT04533399).

\subsection{Virus Like Particles (VLPs)}

Vaccines based on the virus-like particles may incorporate recombinant protein with adjuvants, lipid nanoparticles encapsulated mRNA, peptide VLPs etc. The innovative approach in SARS-CoV-2 vaccine preparation is being pursued by ExpreS2ion company which uses Drosophila S2 insect cell expression system. Preclinical investigation of Medicago Inc. is using plant-based VLP [46]. They are often regarded as 'empty virus shell'- empty coronavirus outer surface structures that are non infectious, but can be used to load peptides or proteins along with adjuvants [59].

VLPs are viral particles that do not contain any RNA or DNA, but have protein as antigens. The varying antigenic nature of VLPs is associated with their size, shape, structure and surface that triggers the immune system significantly. Preliminary studies, however, suggest a lower antibody titer and mild local reactions at the site of intramuscular injection. A VLP vaccine developed by Medicago is a plant derived anti COVID-19 vaccine, added with either of the two different adjuvants (GSK's adjuvant technology and Dynavax's CpG 1018) undergoing Phase I clinical trials (NCT04450004) [65].

\subsection{Inactivated Viral Vaccines}

Inactivated viral vaccines can be formulated in a faster manner as compared to other type of vaccines. The virus is reduced to noninfectious one with chemical or physical methods like heat, formalin, UV light, formaldehyde, $\beta$ propiolactone, etc. They have better stability but require a booster dose of immunization. Gamma-ray inactivated whole MERS-CoV vaccine studies show complications such as pulmonary eosinophilia, but the same vaccine, when treated with formaldehyde and alum, shows superior lung pathology $[66,67]$. Sinovac is conducting two separate preclinical trials of inactivated SARS-CoV-2 vaccine with alum and CpG 1018 adjuvant [46].

This conventional vaccine formulation technology is said 
to be safest and time tested with a previous high success rate of polio, influenza and hepatitis vaccines. In the case of COVID-19 vaccine, SARS-CoV-2 culture is prepared from isolates obtained from hospitalized COVID-19 patients. Inactivation of the whole virus is achieved by treatment with $\beta$ propiolactone. There are several different vaccines under clinical trials for COVID-19 treatment. Prominent vaccines include - BBIBP-CorV vaccine developed by Beijing Institute of Biological Products/Sinopharm, CoronaVac developed by Sinovac and Covaxin developed and manufactured by Bharat Biotech-ICMR in collaboration. CoronaVac has received emergency use approval in China and Phase 3 clinical trials are being conducted in Brazil, Turkey and Indonesia. Initial studies have reported $50.4 \%$ efficacy against COVID-19 in trials at several locations in Brazil [47, 68].

\subsection{Live Attenuated Viral Vaccines}

Attenuated vaccines have weakened virulence and pathogenicity but retaining antigenic nature to elicit an immune response from the host. This is a conventional and proven method, usually prepared by the cultivation of microorganisms in the laboratory or successive subculturing to alter the virulence [69]. Codagenix, Farmingdale and Serum Institute of India are leading in formulating attenuated vaccines and currently under preclinical investigation [46].

Attenuated virus vaccines mostly stimulate mucosal immunity to reduce the mucosal virus infection, the main advantage being intrinsic immunogenicity and capacity to induce and trigger the toll-like receptors (mainly TLR3, TLR7, TLR8 and TLR9). This vaccine type has several advantages such as exceptional neutralizing antibody titer, ease of development, maintaining antigenicity and compatibility with several adjuvants. A "codon deoptimization" technique developed by Codagenix is developing the SARS-CoV-2 vaccine. Wuhan And Beijing Institute of Biological Products Co. is also advancing in developing an attenuated vaccine and is undergoing Phase 3 clinical trials in several countries (NCT04510207).

\subsection{Novel Types of Viral Vaccines under Investigation}

\subsubsection{Convalescent Plasma Transfusion}

Although not a true form of the vaccine, it contains antibodies from patients recovered from SARS-CoV-2 infection, provided they contain a high titre of neutralizing Antibodies (nAbs). Patients with respiratory distress gain more from this treatment, reduce mortality in critically ill patients as a single dose of convalescent plasma having nAbs $>1: 640$ [70]. At this time, there are no systematic trials conducted on convalescent plasma transfusion for treating SARS-CoV-2 patients. Few weeks followed by infection with SARS-CoV-2, antibodies against viral proteins are formed in patients. At further stage, it is observed that most of the infected patient's serum can fuse with the viral spike protein and neutralize it in vitro. This serum from COVID-19 patients can restrain SARSCoV-2 viral infection upto $50 \%$. Crawford et al. assessed binding and neutralizing antibody titers in plasma samples from 32 SARS-CoV-2-infected persons with a varying disease severity covering 152 days after initial symptoms. They reported that the level of spike protein attaching antibody decreased gradually from initial symptoms to $90^{\text {th }}$ day, accompanied by diminished neutralizing capacity; however, most of the patients had antibodies up to 4 months after the appearance of initial symptoms [71]. However, another study by Ibarrondo et al. demonstrated quick decay of antibody level and anti-RBD titers in the case of patients who are asymptomatic or with mild SARS-CoV-2 infection [72].

Thus, treating patients of COVID-19 with convalescent plasma from previously SARS-CoV-2 infected and recovered donors does not seem to be a standard protocol as neutralizing antibody titer is not the same for all the samples. Further, there are always chances of latent allergenic responses from the recipient that are difficult to predict.

\subsubsection{Monoclonal Antibodies}

Monoclonal antibodies in limited studies have shown targeting capability towards Receptor-Binding Domain (RBD) of spike protein (S), preventing viral attachment of the coronavirus to host cell. These results are positive in few animal models but lack reproducibility [73]. A further detailed evaluation is needed to establish the usefulness of monoclonal antibodies in COVID-19 treatment.

Weinreich et al. carried out a trial of a combination of monoclonal antibodies, casirivimab and imdevimab (called as REGN-COV2), targeted against the spike protein of SARS$\mathrm{CoV}-2$ for early infection patients. Patients injected with REGN-COV2 had lower SARS-CoV-2 RNA levels as compared to those who received placebo. In another study, bamlanivimab was administered at three doses, results indicating decline in SARS-CoV-2 RNA levels on $4^{\text {th }}$ day of treatment, followed by a significant decline in symptoms of COVID-19 compared to placebo effects [74]. As a result of the positive outcome, Operation Warp Speed - National Institutes of Health and Eli Lilly with Regeneron are escalating their studies to investigate further the clinical benefits of their monoclonal antibodies (NCT04518410).

\subsubsection{Membrane Fusion Proteins}

$\mathrm{S} 2$ subunit of surface protein $\mathrm{S}$ in SARS-CoV-2 is responsible for host cell membrane fusion followed by the release of the viral RNA genome in the host cell for replication. In this critical step, the $\mathrm{S} 2$ domain undergoes conformational change for fusion and pore formation to occur between the viral membrane and the host cell membrane [75]. Peptide-like fusion inhibitors HR1 and HR2 in S2 subunit are reported to inhibit the process of fusion. Studies involving MERS-CoV show improved lung pathology in preclinical studies [76]. Spike protein trimer stabilization is an advanced technique generally called as 'molecular clamp', being used for development of vaccine by collaborative project of CSL and Seqirus in partnership with University of Queensland. Phase 1 clinical trials are undergoing in Australia which is preceded by satisfactory pre-clinical studies [48].

\subsubsection{Adeno Associated Virus (AAV) based Gene Therapy}

Several types of commonly used viral vectors causing mild to no symptoms on infection in humans are available, such as 
an adeno-associated virus (AAV). Adenovirus vector has been proven safe for multiple treatments in humans. One such vaccine development strategy is being used at the AAVCOVID vaccine development program at Massachusetts Eye and Ear and Massachusetts General Hospital (MGH) - affiliates of Harvard Ophthalmology. In this particular strategy, AAV delivers genetic sequences of the Spike antigen present in SARS-CoV-2, allowing the host immune system to develop antibodies specific to coronavirus. Previous clinical uses of AAV gene therapy have been proven successful with a consistent and favorable safety record [77]. The advantage of AAV-based vaccines is that only a single dose is required, which improves antibody titer from $14^{\text {th }}$ to $28^{\text {th }}$ day of the dose. Several COVID-19 vaccine are under development by this technique, such as CanSino (Adenovirus type 5), AstraZeneca's ChAdOx1 nCoV-19 uses chimpanzee adenovirus that encodes $\mathrm{S}$ protein and a vaccine by Janssen (Adenovirus type 26). Among the few companies developing oral COVID-19 vaccines, Vaxart is in the development of a nonreplicating oral adenovirus vaccine that can prevent infection by triggering a mucosal immune response [48].

\section{INDIAN PERSPECTIVE ON CORONAVIRUS VACCINE DEVELOPMENT}

More than 10 COVID-19 vaccines are under development in India. The progress in this direction is being updated continuously on the web portal (https://vaccine.icmr.org.in/COVID-19-vaccine) maintained by the Indian Council of Medical Research. Currently, three different vaccines are jointly developed in collaboration with various agencies. This can be summarized in a nutshell in the following Table $\mathbf{3}$.

The vaccines being developed in India are in human clinical trials Phase II/III, which enroll healthy human volunteers for establishing clinical efficacy of the vaccines. All the details are updated regularly on the website https://vaccine.icmr.org.in/. While Covaxin is approved against COVID-19, Covishield has been given emergency use authorization. The vaccination has started with priority to frontline health workers followed by those aged above 45 years and with co-morbidity.

\section{GLOBAL PERSPECTIVE OF COVID-19 AND PROGRESS IN VACCINATION}

Several countries have witnessed a rise in cases as well as deaths due to the second wave of COVID-19. In addition, this is accompanied by the appearance and spread of new strains of SARS-CoV-2 (B.1.1.7 variant in UK and B.1.351 in South Africa). The rise in positive cases and deaths initially caused hesitancy and the spread of misinformation about vaccination against COVID-19. However, researchers and scientists have reassured the importance of vaccination and emphasis on getting vaccinated to avoid the catastrophic situation. In fact, in UK, strict lockdown followed by aggressive vaccination has shown better future with declining number of cases as well as lesser mortalities since mid of January 2021 [78]. Similar trends are observed in Israel, United Arab Emirates, and Norway, which have started vaccinating citizens at an incredible pace [79]. However, in several countries like Brazil, Pakistan, and India, the patients of COVID-19 are increasing with higher mortalities. Thus, it becomes imperative that apart from maintaining physical distance and wearing a mask, getting vaccinated must be prioritized by people and supported robustly by governments, administrations and allied organization as early as and as quickly as possible.

The difficulty and concerns initially thought about reaching the vaccine to every country with equity and equality, diligently and at affordable prices, has been addressed by several organizations. The Global Alliance for Vaccines and Immunizations (GAVI), COVID-19 Vaccines Global Access (COVAX), WHO, Coalition for Epidemic Preparedness Innovations (CEPI), and UNICEF are ensuring vaccine delivery with logistical supports. In the end, the road for normalcy goes through the path of vaccination only.

\section{DISCUSSION}

COVID-19 is a new entrant in viral disease, starting with 'common cold' rapidly covered the globe with alarming mortality and co-morbidity and eventually declared a pandemic by WHO on $11^{\text {th }}$ march 2020 . In order to restrain the spread of infection, governments in almost all affected countries declared lockdown, social distancing, repeated hand washing and use of face masks with the prohibition of mass gatherings.

Table 3. Current status of COVID 19 vaccines being developed in India

\begin{tabular}{|c|c|c|c|}
\hline $\begin{array}{l}\text { Name of the } \\
\text { Vaccine }\end{array}$ & Developer & Current Status & References \\
\hline COVAXIN & $\begin{array}{l}\text { Bharat Biotech and } \\
\text { ICMR }\end{array}$ & $\begin{array}{c}\text { Completed Adaptive, Seamless Phase I trials, followed } \\
\text { by ongoing Phase II Double blind, Randomized, } \\
\text { Multicentre Study for evaluation of Safety, Tolerability } \\
\text { and Immunogenicity. }\end{array}$ & \multirow{3}{*}{$\begin{array}{c}1 . \\
\text { https://vaccine.icmr.org.in/COVID-19-vaccine } \\
\text { Indian Council of medical research } \\
\text { And } \\
\text { 2. http://ctri.nic.in/Clinicaltrials/login.php } \\
\text { Clinical Trials Registry of India }\end{array}$} \\
\hline COVISHIELD & \begin{tabular}{|c|} 
Oxford and \\
AstraZeneca, \\
ICMR and Serum \\
Institute Of India \\
are conducting \\
clinical trials \\
\end{tabular} & $\begin{array}{c}\text { A Phase II and III, Observer-Blind, Randomized } \\
\text { Controlled Study to Determine the Safety and } \\
\text { Immunogenicity of Covishield (COVID-19 Vaccine) in } \\
\text { Healthy Indian Adults age range } 18 \text { to } 99 \text { years. Phase } \\
\text { II Human clinical trials ongoing. }\end{array}$ & \\
\hline ZyCoV-D & Zydus Cadila & $\begin{array}{l}\text { A plasmid DNA vaccine to prevent. Safety in Phase I } \\
\text { clinical trial of ZyCoV-D in healthy subjects } \\
\text { established as endorsed by the independent Data Safety } \\
\text { Monitoring Board (DSMB). Zydus commenced the } \\
\text { Phase II trial. }\end{array}$ & \\
\hline
\end{tabular}


It was mandated by experts from all over the world that the lack of a specific treatment plan makes it imperative to develop a vaccine for COVID-19. There are calculated clinical uses of Hydroxychloroquin, remedisivir, favipiravir, but without previous history of use against SARS-CoV. This has compelled researchers to hunt for suitable, safe vaccines. In the usual course, the vaccine development in a conventional way takes from 10 to 15 years. The current situation thus paves the way for bypassing/substituting regulatory phases of clinical trials to accelerate vaccine development for COVID-19 with an unconventional approach. Irrespective of the technology platform used, experts are concerned about the safety and efficacy issues, although CEPI, NIH, NIAID, CDC and FDA are trying their best to address them.

The significant requirement to address the COVID-19 pandemic has prompted the development of several vaccine candidates which can address the worldwide vaccine burden. The accomplishments, achievement and vaccine efficacy as outlined above further authenticate foundation of the hard work of scientific research in vaccine development. The effect of COVID-19 vaccine development has resulted in an unparalleled speed of vaccine design and manufacturing. The theoretical concepts and the premise of platforms that only require antigens, like mRNA and vector-based technology, have accelerated their development towards quick Phase 3 evaluation. Almost all the vaccines reaching Phase 3 of clinical trials have reported efficacy in a well acceptable range, with some of them more than $90 \%$. While many vaccines require a booster dose, viral vector vaccines with single-dose efficacy are in Phase 3 clinical trials and are much awaited. Since the vaccines currently produced mainly focus on neutralizing antibody generation in the host, a more holistic approach is needed that will aim to achieve long-term immunity against COVID-19. At the same time, a broader approach towards vaccine development is growing as newer variants are emerging from South Africa (B.1.351), UK (B.1.1.7) and Brazil (B.1.1.28). The possible way out for this can be developing broad activity vaccines that target structural proteins apart from protein S, such as ORF7A and ORF3A, which can prevent transmembrane entry as well as adherence of SARS-CoV-2 to the host cells by extended $\mathrm{T}$ cell and B cell immunity for a longer duration.

As a matter of concern, recently there have been reports of blood clots and hemorrhage associated with the administration of the Oxford-AstraZeneca COVID-19 vaccine. This has raised apprehension about vaccine safety in Europe. Thus, an extensive review is being exercised by Medicine and Healthcare Regulatory Authority, UK (MHRA) and European Medicines Agency (EMA) [80]. This emphasizes the need for detailed safety evaluation of vaccines, mainly while considering patients with chronic co-morbidities. However, it can be fairly concluded that the advantages of vaccines greatly outweigh their rare incidences of side effects.

Finally, the progress in vaccination in several countries has reaffirmed that with proven reports and records, gradually COVID-19 cases are declining along with drop-in mortality rate. Vaccinating vulnerable populations is the only path ahead to get rid of COVID-19.

\section{CONCLUSION}

As the Coronavirus disease progresses, it delivers more information about the virus, replication pattern, spread, epidemiology, clinical outcomes, risk age group, and much more. This has ultimately helped in developing the right approach for vaccine development against SARS-CoV-2. At the same time, previous viral diseases emerged in the last 20 years, prompted for vaccine development with limited success. This sets the tone for the use of a myriad of technology platforms - live, attenuated, virus like a particle, vectors, mRNA, protein subunit, DNA type for vaccine development with new paradigms in testing and evaluation of vaccines.

Formulation of vaccine, along with dosage and suitable adjuvants, need to be tested systemically on animal models, which helps to identify the genetic variations in demographies worldwide. The efforts need to be escalated as COVID-19 is taking a toll on lives and economy in all countries as notified by UNO.

As more and new formulations of vaccines are being tested, each bringing a new technology in vaccine design and development, hopefulness about control of the COVID-19 pandemic grows. However, considerations of viral mutations, new strains and variants, supply chain management-logistics and delivery to the citizens must be looked after continuously by all the concerned authorities, off-course maintaining social distance and use of mask will add up to prevent the spread of disease and ease the pandemic burden.

As a concluding remark, it is conceivably advisable that a single or couple of vaccines will not suffice to whole population vaccination with constraints mentioned above, thus simultaneous use of multiple vaccines must be explored as soon as possible.

\section{CONSENT FOR PUBLICATION}

Not applicable.

\section{FUNDING}

None.

\section{CONFLICT OF INTEREST}

The authors declare no conflict of interest, financial or otherwise.

\section{ACKNOWLEDGEMENTS}

Declared none.

\section{REFERENCES}

[1] Paules CI, Marston HD, Fauci AS. Coronavirus infections - more than just the common cold. Jama 2020; 323(8): 707-8. [http://dx.doi.org/10.1001/jama.2020.0757]

[2] Jiang S, Hillyer C, Du L. Neutralizing antibodies against SARS-CoV-2 and other human coronaviruses. Trends Immunol 2020; 41(5): 355-9. [http://dx.doi.org/10.1016/j.it.2020.03.007] [PMID: 32249063]

[3] WHO. WHO Director-General's opening remarks at the media briefing on COVID-19. 2020. Available from: https://www.who.int/dg/speeches/detail/who-director-general-s-openin g-remarks-at-the-media-briefing-on-COVID-19---11-march-2020

[4] WHO. WHO Coronavirus Disease (COVID-19) Dashboard. 2020; 1-2. Available from: https://covid19.who.int/ 
[5] Pandey SC, Pande V, Sati D, Upreti S, Samant M. Vaccination strategies to combat novel corona virus SARS-CoV-2. Life Sciences 2020; $256: 117956$.

[http://dx.doi.org/10.1016/j.lfs.2020.117956] [PMID: 32535078]

[6] Belouzard S, Millet JK, Licitra BN, Whittaker GR. Mechanisms of coronavirus cell entry mediated by the viral spike protein. Viruses 2012; 4(6): 1011-33.

[http://dx.doi.org/10.3390/v4061011] [PMID: 22816037]

[7] Pitout JDD, Finn TJ. The evolutionary puzzle of Escherichia coli ST131. Infec Gene Evol 2020; 2019: 104265.

[http://dx.doi.org/10.1016/j.meegid.2020.104265] [PMID: 32112974]

[8] Boopathi S, Poma AB, Kolandaivel P. Novel 2019 coronavirus structure, mechanism of action, antiviral drug promises and rule out against its treatment. J Biomol Struc Dynam 2021; 39(9): 3409-18. [http://dx.doi.org/10.1080/07391102.2020.1758788] [PMID 32306836]

[9] Gupta MK, Vemula S, Donde R, Gouda G, Behera L, Vadde R. Insilico approaches to detect inhibitors of the human severe acute respiratory syndrome coronavirus envelope protein ion channel. J Biomol Struc Dyn 2021; 39(7): 2617-7.

[http://dx.doi.org/10.1080/07391102.2020.1751300] [PMID: 32238078]

[10] Hasan A, Paray BA, Hussain A, Qadir FA, Attar F, Aziz FM, et al. A review on the cleavage priming of the spike protein on coronavirus by angiotensin-converting enzyme-2 and furin. J Biomol Struct Dyn 2020; $1-9$.

[http://dx.doi.org/10.1080/07391102.2020.1754293] [PMID: 32274964]

[11] Seah I, Su X, Lingam G. Revisiting the dangers of the coronavirus in the ophthalmology practice. Eye (Lond) 2020; 34(7): 1155-7. [http://dx.doi.org/10.1038/s41433-020-0790-7] [PMID: 32029919]

[12] Beigel JH, Tomashek KM, Dodd LE, et al. Remdesivir for the treatment of COVID-19 - Final report. N Engl J Med 2020; 383(19): 1813-26.

[http://dx.doi.org/10.1056/NEJMoa2007764] [PMID: 32445440]

[13] Wang Y, Zhang D, Du G, et al. Remdesivir in adults with severe COVID-19: A randomised, double-blind, placebo-controlled, multicentre trial. Lancet 2020; 395(10236): 1569-78. [http://dx.doi.org/10.1016/S0140-6736(20)31022-9]

[PMID: 32423584]

[14] Wang J, Peng Y, Xu H, Cui Z, Williams RO III. The COVID-19 vaccine race: Challenges and opportunities in vaccine formulation. AAPS PharmSciTech 2020; 21(6): 225.

[http://dx.doi.org/10.1208/s12249-020-01744-7] [PMID: 32761294]

[15] Roback JD, Guarner J. Convalescent Plasma to Treat COVID-19: Possibilities and Challenges. JAMA 2020; 323(16): 1561-2.

[http://dx.doi.org/10.1001/jama.2020.4940] [PMID: 32219429]

[16] Duan K, Liu B, Li C, Zhang H, Yu T, Qu J, et al. 2020. Available from: http://www.pnas.org/content/117/17/9490

[17] Wu K, Werner AP, Moliva JI, et al. mRNA-1273 vaccine induces neutralizing antibodies against spike mutants from global SARSCoV-2 variants. BioRxiv 2021.

[http://dx.doi.org/10.1101/2021.01.25.427948]

[18] News $\quad$ B. Available https://www.bbc.com/news/world-latin-america-56598866

[19] Drake JW, Holland JJ. Mutation rates among RNA viruses. Proceed Nation Acad Scienc 1999; 96(24): 13910-3

[http://dx.doi.org/10.1073/pnas.96.24.13910]

[20] Pandey SC, Pande V, Sati D, Upreti S, Samant M. Vaccination strategies to combat novel corona virus SARS-CoV-2. Life Sciences 2020; 256: 117956.

[21] Padron-Regalado E. Vaccines for SARS-CoV-2: Lessons from other coronavirus strains. Infect Dis Ther 2020; 9(2): 1-20. [http://dx.doi.org/10.1007/s40121-020-00300-x] [PMID: 32328406]

[22] Lauring AS, Andino R. Quasispecies theory and the behavior of RNA viruses. PLoS Pathog 2010; 6(7): e1001005.

[http://dx.doi.org/10.1371/journal.ppat.1001005] [PMID: 20661479]

[23] Li F. Structure, function, and evolution of coronavirus spike proteins. Annu Rev Virol 2016; 3(1): 237-61.

[http://dx.doi.org/10.1146/annurev-virology-110615-042301] [PMID: 27578435]

[24] Kandeel M. Bioinformatics analysis of the recent MERS-CoV with special reference to the virus-encoded Spike protein. Mol Enzymol Drug Targets 2015; 01(01): 1-10.

[http://dx.doi.org/10.21767/2572-5475.10001]

[25] Alharbi NK, Padron-Regalado E, Thompson CP, et al. ChAdOx1 and MVA based vaccine candidates against MERS-CoV elicit neutralising antibodies and cellular immune responses in mice. Vaccine 2017; 35(30): 3780-8.

[http://dx.doi.org/10.1016/j.vaccine.2017.05.032] [PMID: 28579232]

[26] Wang Q, Zhang L, Kuwahara K, et al. Immunodominant SARS coronavirus epitopes in humans elicited both enhancing and neutralizing effects on infection in non-human primates. ACS Infect Dis 2016; 2(5): 361-76.

[http://dx.doi.org/10.1021/acsinfecdis.6b00006] [PMID: 27627203]

[27] Okba NM, Raj VS, Haagmans BL. Middle east respiratory syndrome coronavirus vaccines: Current status and novel approaches. In: Curr Opin Virol. 2017; Vol. 23: pp. 49-58.

[28] Kam YW, Kien F, Roberts A, et al. Antibodies against trimeric S glycoprotein protect hamsters against SARS-CoV challenge despite their capacity to mediate FcgammaRII-dependent entry into B cells in vitro. Vaccine 2007; 25(4): 729-40.

[http://dx.doi.org/10.1016/j.vaccine.2006.08.011] [PMID: 17049691]

[29] Jiang S. Don't rush to deploy COVID-19 vaccines and drugs without sufficient safety guarantees. Nature 2020; 579(7799): 321.

[http://dx.doi.org/10.1038/d41586-020-00751-9] [PMID: 32179860]

[30] Curiel RP, Ramírez HG. Vaccination strategies against COVID-19 and the diffusion of anti-vaccination views arXiv 2020; (0123456789): $1-13$.

[http://dx.doi.org/10.1038/s41598-021-85555-1]

[31] Troiano G, Nardi A. Vaccine hesitancy in the era of COVID-19. Public Health 2021; 194: 245-51.

[http://dx.doi.org/10.1016/j.puhe.2021.02.025] [PMID: 33965796]

[32] Bao L, Deng W, Huang B, et al. The pathogenicity of SARS-CoV-2 in hACE2 transgenic mice. Nature 2020; 583(7818): 830-3.

[http://dx.doi.org/10.1038/s41586-020-2312-y] [PMID: 32380511]

[33] Services H. Vaccine types. 2019; pp. 2-7. Available from: https://www.vaccines.gov/basics/types

[34] Han S. Clinical vaccine development. Clin Exp Vaccine Res 2015; 4(1): 46-53. Available from: https://ecevr.org/DOIx.php?id=10.7774/cevr.2015.4.1.46

[http://dx.doi.org/10.7774/cevr.2015.4.1.46] [PMID: 25648742]

[35] Leroux-Roels G. Unmet needs in modern vaccinology: adjuvants to improve the immune response. Vaccine 2010; 28(Suppl. 3): C25-36. [http://dx.doi.org/10.1016/j.vaccine.2010.07.021] [PMID: 20713254]

[36] Harandi AM, Davies G, Olesen OF. Vaccine adjuvants: Scientific challenges and strategic initiatives. Expert Rev Vaccines 2009; 8(3): 293-8.

[http://dx.doi.org/10.1586/14760584.8.3.293] [PMID: 19249971]

[37] He C, Qin M, Sun X. Highly pathogenic coronaviruses: thrusting vaccine development in the spotlight. Acta Pharm Sin B 2020; 10(7): 1175-91.

[http://dx.doi.org/10.1016/j.apsb.2020.05.009] [PMID: 32834948]

[38] Trogen B, Oshinsky D, Caplan A. Adverse consequences of rushing a SARS-CoV-2 Vaccine: Implications for public trust. JAMA 2020; 323(24): 2460-1.

[http://dx.doi.org/10.1001/jama.2020.8917] [PMID: 32453392]

[39] Plotkin SA, Caplan A. Extraordinary diseases require extraordinary solutions. Vaccine 2020; 38(24): 3987-8.

[http://dx.doi.org/10.1016/j.vaccine.2020.04.039] [PMID: 32331807]

[40] Calina D, Docea AO, Petrakis D, et al. Towards effective COVID-19 vaccines: Updates, perspectives and challenges (Review). Int J Mol Med 2020; 46(1): 3-16.

[http://dx.doi.org/10.3892/ijmm.2020.4596] [PMID: 32377694]

[41] Centers for Disease Control and Prevention. People who are at highe risk for severe illness Coronavirus Disease 2019 (COVID-19) 2020; 68: 703-10. Available from https://www.cdc.gov/coronavirus/2019-ncov/need-extra-precautions/p eople-at-higher-risk.html

[42] Begley S. Who is getting sick, and how sick? A breakdown of coronavirus risk by demographic factors. In: Bostoncom. 2021; pp. 1-7. Available from: https://www.boston.com/news/health/2020/03/03/who-is-getting-coron avirus/

[43] Eyal N, Lipsitch M, Smith PG. Human challenge studies to accelerate coronavirus vaccine licensure. J Infect Dis 2020; 221(11): 1752-6. [http://dx.doi.org/10.1093/infdis/jiaa152] [PMID: 32232474]

[44] ClinicalTrials.gov Search Results. 2020; 2020. Available from: https://clinicaltrials.gov/ct2/results?pg=1\&load=cart\&id=NCT042834 61

[45] National Institute of Allergy and Infectious Diseases NIH clinical trial of investigational vaccine for COVID-19 begins | NIH: National Institute of Allergy and Infectious Diseases 2019; 2-5. Available from: https://www.nih.gov/news-events/news-releases/nih-clinical-trial-inves 
tigational-vaccine-COVID-19-begins $\% 0 \mathrm{~A}$

[46] WHO. Draft landscape of COVID-19 candidate vaccines 2020; 3 . Available from: https://www.who.int/publications/m/item/draft-landscape-of-COVID-1 9-candidate-vaccines $\% 0 \mathrm{D}$

[47] Chakraborty S, Mallajosyula V, Tato CM, Tan GS, Wang TT. SARSCoV-2 vaccines in advanced clinical trials: Where do we stand? Adv Drug Deliv Rev 2021; 172: 314-38.

[http://dx.doi.org/10.1016/j.addr.2021.01.014] [PMID: 33482248]

[48] Batty CJ, Heise MT, Bachelder EM, Ainslie KM. Vaccine formulations in clinical development for the prevention of severe acute respiratory syndrome coronavirus 2 infection. Adv Drug Deliv Rev 2021; 169: 168-89.

[http://dx.doi.org/10.1016/j.addr.2020.12.006] [PMID: 33316346]

[49] Jhaveri R. The next set of COVID-19 vaccines: Leveraging new development platforms to increase access for more people around the world. Clin Ther 2021; S0149-2918(21)00119-3.

[http://dx.doi.org/10.1016/j.clinthera.2021.03.007] [PMID: 33832783]

[50] Palacios R, Mathias A. Learning from combination HIV prevention programmes to face COVID-19 emerging pandemic. Colombia Médica 2020; 51(2)

[http://dx.doi.org/10.25100/cm.v51i2.4276]

[51] Kuo T-Y, Lin M-Y, Coffman RL, et al. Development of CpGadjuvanted stable prefusion SARS-CoV-2 spike antigen as a subunit vaccine against COVID-19. Sci Rep 2020; 10(1): 20085 [http://dx.doi.org/10.1038/s41598-020-77077-z] [PMID: 33208827]

[52] Bangaru S, Ozorowski G, Turner HL, et al. Structural analysis of fulllength SARS-CoV-2 spike protein from an advanced vaccine candidate. Science 2020; 370(6520): 1089-94.

[http://dx.doi.org/10.1126/science.abe1502]

[53] Maruggi G, Zhang C, Li J, Ulmer JB, Yu D. mRNA as a transformative technology for vaccine development to control infectious diseases. Mol Ther 2019; 27(4): 757-72. [http://dx.doi.org/10.1016/j.ymthe.2019.01.020] [PMID: 30803823]

[54] Kramps T, Probst J. Messenger RNA-based vaccines: progress, challenges, applications. Wiley Interdiscip Rev RNA 2013; 4(6): 737-49.

[http://dx.doi.org/10.1002/wrna.1189] [PMID: 23893949]

[55] Farsalinos K, Niaura R, Le Houezec J, et al. Editorial: Nicotine and SARS-CoV-2: COVID-19 may be a disease of the nicotinic cholinergic system. Toxicol Rep 2020; 7: 658-63.

[http://dx.doi.org/10.1016/j.toxrep.2020.04.012] [PMID: 32355638]

[56] Hobernik D, Bros M. DNA vaccines-how far from clinical use?. In: Int J Mol Sci. 2018; 19: p. (11)3605

[http://dx.doi.org/10.3390/ijms19113605]

[57] Corbett KS, Edwards DK, Leist SR, et al. SARS-CoV-2 mRNA vaccine design enabled by prototype pathogen preparedness. Nature 2020; 586(7830): 567-71.

[http://dx.doi.org/10.1038/s41586-020-2622-0] [PMID: 32756549]

[58] Ura T, Okuda K, Shimada M. Developments in viral vector-based vaccines. Vaccines (Basel) 2014; 2(3): 624-41.

[http://dx.doi.org/10.3390/vaccines2030624] [PMID: 26344749]

[59] Callaway E. The race for coronavirus vaccines: A graphical guide. Nature 2020; 580(7805): 576-7.

[http://dx.doi.org/10.1038/d41586-020-01221-y] [PMID: 32346146]

[60] Zhu F-C, Guan X-H, Li Y-H, et al. Immunogenicity and safety of a recombinant adenovirus type-5-vectored COVID-19 vaccine in healthy adults aged 18 years or older: a randomised, double-blind, placebocontrolled, phase 2 trial. Lancet 2020; 396(10249): 479-88. [http://dx.doi.org/10.1016/S0140-6736(20)31605-6] 32702299]

[61] Folegatti PM, Ewer KJ, Aley PK, et al. Safety and immunogenicity of the ChAdOx $1 \mathrm{nCoV}-19$ vaccine against SARS-CoV-2: a preliminary report of a phase $1 / 2$, single-blind, randomised controlled trial. Lancet 2020; 396(10249): 467-78.

[http://dx.doi.org/10.1016/S0140-6736(20)31604-4] [PMID: 32702298]

[62] Lan J, Deng Y, Chen H, et al. Tailoring subunit vaccine immunity with adjuvant combinations and delivery routes using the Middle East Respiratory Coronavirus (MERS-CoV) receptor-binding domain as an antigen. PLoS One 2014; 9(11): e112602.

[http://dx.doi.org/10.1371/journal.pone.0112602] [PMID: 25405618]

[63] Du L, Zhao G, Chan CC, et al. A 219-mer CHO-expressing receptorbinding domain of SARS-CoV $\mathrm{S}$ protein induces potent immune responses and protective immunity. Viral Immunol 2010; 23(2): 211-9. [http://dx.doi.org/10.1089/vim.2009.0090] [PMID: 20374001]

[64] Tian J-H, Patel N, Haupt R, Zhou H, Weston S, Hammond H, et al. SARS-CoV-2 spike glycoprotein vaccine candidate NVX-CoV2373 immunogenicity in baboons and protection in mice. Nature Commun 2021; 12(1): $1-4$

[http://dx.doi.org/10.1038/s41467-020-20653-8]

[65] Ward BJ, Gobeil P, Séguin A, Atkins J, Boulay I, Charbonneau P-Y, et $a l$. Phase 1 trial of a candidate recombinant virus-like particle vaccine for COVID-19 disease produced in plants. medRxiv 2020 [http://dx.doi.org/doi.org/10.1101/2020.11.04.20226282]

[66] Agrawal AS, Tao X, Algaissi A, et al. Immunization with inactivated middle east respiratory syndrome coronavirus vaccine leads to lung immunopathology on challenge with live virus. Hum Vaccin Immunother 2016; 12(9): 2351-6.

[http://dx.doi.org/10.1080/21645515.2016.1177688] [PMID: 27269431]

[67] Rabaan AA. Middle East respiratory syndrome coronavirus: Five years later. Expert Rev Respir Med 2017; 11(11): 901-12. [http://dx.doi.org/10.1080/17476348.2017.1367288]

[PMID: 28826284]

[68] Zhang Y, Zeng G, Pan H, et al. Safety, tolerability, and immunogenicity of an inactivated SARS-CoV-2 vaccine in healthy adults aged 18-59 years: a randomised, double-blind, placebocontrolled, phase 1/2 clinical trial. Lancet Infect Dis 2021; 21(2): 181-92.

[http://dx.doi.org/10.1016/S1473-3099(20)30843-4]

[PMID: 33217362]

[69] Lauring AS, Jones JO, Andino R. Rationalizing the development of live attenuated virus vaccines. Nat Biotechnol 2010; 28(6): 573-9. [http://dx.doi.org/10.1038/nbt.1635] [PMID: 20531338]

[70] Rajendran K, Krishnasamy N, Rangarajan J, Rathinam J, Natarajan M, Ramachandran A. Convalescent plasma transfusion for the treatment of COVID-19: Systematic review. J Med Virol 2020.

[http://dx.doi.org/10.1002/jmv.25961]

[71] Crawford KHD, Dingens AS, Eguia R, et al. Dynamics of neutralizing antibody titers in the months after severe acute respiratory syndrome coronavirus 2 infection. J Infect Dis 2021; 223(2): 197-205. [http://dx.doi.org/10.1093/infdis/jiaa618] [PMID: 33535236]

[72] Ibarrondo FJ, Fulcher JA, Goodman-Meza D, et al. Rapid decay of anti-SARS-CoV-2 antibodies in persons with mild COVID-19. N Engl J Med 2020; 383(11): 1085-7. [http://dx.doi.org/10.1056/NEJMc2025179] [PMID: 32706954]

[73] Zhu Z, Chakraborti S, He Y, Roberts A, Sheahan T, Xiao X, et al. Potent cross-reactive neutralization of SARS coronavirus isolates by human monoclonal antibodies. Proc Natl Acad Sci 2007; 104(29): 12123-8.

[http://dx.doi.org/10.1073/pnas.0701000104]

[74] Cohen MS. Monoclonal antibodies to disrupt progression of early COVID-19 infection. N Engl J Med 2021; 384(3): 289-91. [http://dx.doi.org/10.1056/NEJMe2034495] [PMID: 33471984]

[75] Walls AC, Xiong X, Park Y-J, et al. Unexpected receptor functional mimicry elucidates activation of coronavirus fusion. Cell 2019; 176(5): 1026-1039.e15.

[http://dx.doi.org/10.1016/j.cell.2018.12.028] [PMID: 30712865]

[76] Channappanavar R, Lu L, Xia S, et al. Protective effect of intranasal regimens containing peptidic middle east respiratory syndrome coronavirus fusion inhibitor against MERS-CoV infection. J Infect Dis 2015; 212(12): 1894-903.

[http://dx.doi.org/10.1093/infdis/jiv325] [PMID: 26164863]

[77] Advancing Novel Experimental Gene-based COVID-19 Vaccine. AAVCOVID 2020; 2020. Available from: https://eye.hms.harvard.edu/news/harvard-ophthalmology-advancing-n ovel-experimental-gene-based-COVID-19-vaccine-aavcovid\#

[78] Wise J. COVID-19: Is vaccination roll out reducing cases and deaths in the UK? BMJ 2021; 372(506): n506.

[http://dx.doi.org/10.1136/bmj.n506] [PMID: 33608315]

[79] Services CH, Dean N. Are COVID vaccination programmes working? Scientists seek first clues. Nature Available from: https://www.nature.com/articles/d41586-021-00140-w

[80] Merchant HA. CoViD vaccines and thrombotic events: EMA issued warning to patients and healthcare professionals. J Pharm Policy Pract 2021; 14(1): 32.

[http://dx.doi.org/10.1186/s40545-021-00315-w] [PMID: 33761987]

\section{(C) 2021 Moharir et al.}

This is an open access article distributed under the terms of the Creative Commons Attribution 4.0 International Public License (CC-BY 4.0), a copy of which is available at: https://creativecommons.org/licenses/by/4.0/legalcode. This license permits unrestricted use, distribution, and reproduction in any medium, provided the original author and source are credited. 